\title{
Correlation of Authoritative Parenting Style and Discipline of Study Toward Students' Mathematics Knowledge Competence
}

\author{
Dewa Putu Reza Setiawan ${ }^{1}$ \\ ${ }^{123}$ Prodi Pendididikan Guru Sekolah Dasar, Universitas Pendidikan Ganesha, Singaraja, Bali, Indonesia
}

\author{
A R T I CLEINFO \\ Article history: \\ Received 2 Juni 2020 \\ Received in revised form \\ 12 Juli 2020 \\ Accepted 10 Agustus 2020 \\ Available online 28 Agustus \\ 2020 \\ kata kunci: \\ Pola Asuh Demokratis, \\ Disiplin, Matematika \\ keywords: \\ Authoritative Parenting \\ Style, Disciple, Mathematics
}

\begin{abstract}
A B S T R A K
Kemampuan siswa SD dalam menguasai kompetensi pengetahuan matematika dapat dipengaruhi oleh berbagai faktor, yakni disiplin belajar siswa dan penerapan pola asuh oleh orang tua. Beberapa orang tua masih belum menyadari bahwa pola pengasuhan yang diterapkan di rumah dapat mempengaruhi hasil belajar anaknya, oleh karena itu penelitian ini bertujuan untuk mengetahui pengaruh tipe pola asuh demokratis dan disiplin belajar terhadap kompetensi pengetahuan matematika. jenis penelitian yang digunakan adalah penelitian ex-post facto dengan desain penelitian korelasional. Populasi yang digunakan dalam penelitian ini adalah seluruh siswa di SD Negeri Gugur I Gusti Ngurah Jelantik yang berjumlah 178 siswa. Sampel diambil menggunakan teknik Proportional Random Sampling. Hasil yang diperoleh dari analisis regresi ganda ditemukan persamaan $\hat{Y}=8.205+0.958 \mathrm{X} 1+0.358 \mathrm{X} 2$ dan hasil Fhitung $=$ $84.209>$ Ftabel $=3.075$. Sehingga nilai Fhitung signifikan. Koefisien determinasi $(R 2)=0.594$. Berdasarkan hasil pengujian, dapat disimpulkan
\end{abstract} bahwa terdapat pengaruh yang signifikan antara tipe pola asuh demokratis dan disiplin belajar terhadap kompetensi pengetahuan matematika siswa kelas V SD Negeri Gugus I Gusti Ngurah Jelantik, Kecamatan Denpasar Utara dengan persentase 59.4\%.

\section{A B S T R A C T}

Some factors give an impact on the student in elementary school. The discipline of studying and parenting style from the parents. Some of the parents are not realizing that parenting style will give an impact on the study result of their children. This research is aimed to determine the effect of the authoritative parenting style and discipline of studying to the competence of student mathematical knowledge. The type of research that is used is ex-post facto research with correlational research design. The population that used in this research is the fifthgrade students of the State Elementary School Group I Gusti Ngurah Jelantik, amounted to 178 students. The sample is determined by a proportional random sampling technique. The result of multiple regression analysis found the equation $\hat{Y}=8.205+0.958 X 1+0.358 X 2$, and result Freg $=84.209>$ Ftable $=3.075$. The Coefficient of determination $(\mathrm{R} 2)=0.594$. Thus, meant score Freg is significant. Based on the result of the research, it can be concluded that there is a significant influence between the authoritative parenting style and discipline of studying to the competence of student mathematical knowledge of fifth-grade students with the percentage of influence about $59.4 \%$.

\section{Introduction}

Some students still consider mathematics as a subject that is very difficult to understand (Ulhusna \& Diana, 2020). Students who can understand mathematical problems at school are often considered smart by their peers. Meanwhile, students who are less involved in learning mathematics are considered less intelligent students. Parents of students also think that their children are smart if they can master mathematics well. Therefore, when they realize that their child's math score is low, parents will choose to enroll their child in a tutoring or tutoring institution, with the hope that their child's math score will be better and be able to do well in class. They also will not think long enough to spend a large enough money so that their children can show good performance in front of their class teachers. In this condition, the parents only focus on the cognitive abilities of their children. Whereas in the 2013 curriculum, several other aspects must also be applied in a balanced way, namely aspects of attitude and also aspects of skills (Widiasih et al., 2018).

Mathematics learning applied at the elementary school level aims to educate students to be able to think critically, be able to observe various mathematical problems that exist in students'

Copyright (C) Universitas Pendidikan Ganesha. All rights reserved. 
environment carefully, and be able to produce creative ideas in solving the problems they face, both in the home environment, as well as schools and communities (Oktarini et al., 2018). One indicator of the achievement of this goal is that students can master the competence of mathematical knowledge according to the standards set at the primary school level. To be able to master the competence of mathematical knowledge, the most basic thing for students is to master the concept of each mathematics subject matter (Prabaningrum, 2019). In the implementation of learning in the classroom, the teacher explains the concept of things that are general in nature and continue to more abstract things. This general matter can be taken from the phenomena and events that exist in students' daily lives, which also refers to the 2013 curriculum (Juniarti et al., 2020). Strengthening this concept cannot be completed efficiently, students must understand the basics of a mathematical concept so that the role of the teacher is also very important in instilling mathematical concepts into the minds of students.

Several problems are often faced by teachers in implementing mathematics learning in the classroom. One of them is some students who lack discipline when learning activities take place (Adinoto, 2019). Discipline learning is one way to help children develop self-control during the teaching and learning process (Haqqi, 2019). Discipline attitude for students in learning is very important to achieve learning goals so that students are accustomed to being diligent and regular in learning (Ismiyanti, 2018). So that learning carried out in class can run optimally, discipline plays an important role (Nugraheni, 2019). Students who can be disciplined in participating in learning can listen well to the explanations given by the teacher. In addition, the learning atmosphere in the classroom becomes more conducive when students can control their behavior and focus on listening to the material described. This does not only affect students, but also other students (Lestari \& Sugeng, 2019). However, if students do not have discipline in learning, the absorption of the material provided cannot run effectively.

Students cannot focus their minds and end up doing other things outside of classroom learning activities. These activities are carried out individually or in groups, and as a result, can interfere with other students who want to focus on learning. Learning mathematics requires students to be able to focus and think critically and understand concepts in solving mathematical problems (Agustika et al., 2019), according to their respective education levels. If students are not able to understand the mathematical concepts described by the teacher, this will affect the mastery of mathematical knowledge competencies. This theory is in line with the results of research conducted by Dewi (2019) who get the results, namely, there is a significant relationship between learning discipline and mathematics learning outcomes. These results also indicate that the higher the quality of student discipline in learning, the higher the learning outcomes obtained. Not only in mathematics, but learning discipline also affects the learning outcomes of other subjects, this is obtained from the results of research conducted by Diatmika et al. (2017) which indicates that there is a significant positive correlation between the discipline in learning and the fourth-grade students' social studies competence. Learning discipline also affects learning outcomes at higher education levels. Yulia (2017) In his research, the results obtained were that there was a positive and significant relationship between learning discipline and learning concentration on mathematics learning outcomes of grade IX students of SMP.

Another thing from outside the student, which can affect the mastery of the competence of students' mathematical knowledge is the education and parenting patterns applied by parents in the home environment (Reswita, 2017). By nature, parents are obliged to educate and guide their children (Khoirurrohman, 2018). This is because parents have more time with their children, so they have an important role in the child's development (Zuliantini \& Mayasari, 2018). All potential possessed by children grows and develops with the direction and guidance given by parents through parenting (Santosa et al., 2018). Parenting can be interpreted as a strategy applied by parents in stimulating children's development, both physically and spiritually, by equipping children with knowledge, moral values, and standards of behavior following applicable norms (Utami \& Utaminingsih, 2017). Good parenting is applied by parents in the form of parental treatment of children, and the attitudes shown by parents towards children can influence children's learning outcomes (Fadhilah, 2019). In addition, encouragement and support from parents such as preparing the tools and tools needed by children in learning (Dermawan et al., 2018).

The types of parenting that are commonly applied by parents consist of permissive, authoritarian, and authoritative parenting (Santi, 2019). Permissive parenting is a type of parenting that gives freedom to children, and parents do not give strict control to their children. Authoritarian parenting is a parenting style that focuses on binding rules and must be obeyed by the child. Meanwhile, democratic parenting is a parenting style that prioritizes the interests of the child but 
does not hesitate to give control to the child (Sibawaih, 2017). Of the several types of parenting, the type of democratic parenting is considered one of the best parenting styles applied by every parent. This parenting prioritizes the interests of the family in general, rather than the personal interests of both parents and children. So, its application will have a positive impact on children in an environment where the child is (Wenny et al., 2019). Communication between parents and children must be maintained properly to provide education to their children (Sibawaih, 2017). Authoritarian parenting is that parents must be able to form ideal conditions for children to be able to express their opinions and problems they face, especially in learning activities. After children convey their problems, parents and children can exchange opinions to find the best solution to solve the problem. This solution will later be agreed upon by the child, and the child will not feel compelled to implement this decision.

The research carried out by Fitasari (2019) shows that the application of democratic parenting has a positive effect on learning outcomes. Other than that, Santi (2019) also obtained results in his research that there is a correlation between the application of democratic parenting to social studies learning outcomes. As well as research conducted by Widhiasih (2017) The results obtained were that there was a significant effect of the application of democratic parenting on student social studies learning outcomes. Several previous studies have explained that democratic parenting and learning discipline both affect student learning outcomes. However, no researcher specifically explains the effect of the application of democratic parenting and learning discipline on the competence of students' mathematical knowledge. Therefore, the authors consider it necessary to examine this matter to obtain more empirical evidence related to these three variables. So a study was carried out that aims to determine whether there is an effect of the application of the type of democratic parenting and learning discipline on the competence of mathematical knowledge of class V students.

\section{Research Method}

Based on the characteristics of the problem under study, this research is an ex-post-facto type of correlation study. In this study, there were two independent variables and one dependent variable, namely the type of democratic parenting (X1) and learning discipline (X2), while the competence of mathematical knowledge (Y) was the dependent variable. The research design for more details can be seen in Figure 1.

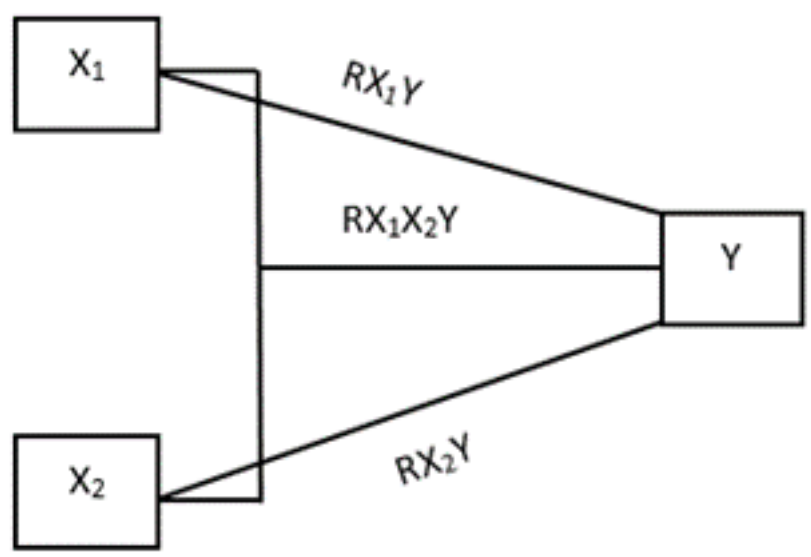

Figure 1. Research Design

A total of 175 students from 3 schools in cluster I Gusti Ngurah Jelantik, North Denpasar District were used as the population in this study. The sampling process was carried out using a proportional random sampling technique. The use of this sampling technique was based on the author\&\#39; s desire to provide opportunities for all sample members to become samples that will later be used in this study. In addition, the selection of this sampling technique also aims to avoid being influenced by elements of subjectivity, so that everyone has the right to be involved in this research as a sample. The sample was determined randomly, without considering the student\&\#39;s school. After going through the randomization process, the samples were then coded to differentiate the samples from one another. The determination of the number of samples was carried out using 
the theory of R.V. Krecjie and D.W. Morgan refers to the table with an alpha level of 5\% for each population. (Agung, 2016). Based on the population size in this study, and if it was adjusted to the table from Krejci and Morgan, the total population that can be used is 118 students.

In this study, a questionnaire was used to measure the application of democratic parenting styles and learning discipline. The questionnaire was based on indicators that are used as a reference in measuring each independent variable. The indicators and the number of statements made in the questionnaire are arranged in a grid, both the questionnaire for the democratic parenting style and the learning discipline questionnaire. The grid of the research instruments used in this study is presented in the following table.

Table 1. Democratic Parenting Type Questionnaire Blueprint

\begin{tabular}{clc}
\hline No & \multicolumn{1}{c}{ Indicators } & Total of Questions \\
\hline 1 & $\begin{array}{l}\text { Provide an understanding that there are equality of } \\
\text { rights and obligations that complement each other } \\
\text { between parents and children }\end{array}$ & 3 \\
2 & Guide children to help each other and act objectively & 3 \\
3 & Instilling responsibility and discipline of children & 3 \\
4 & Provide a reasonable rationale for each action taken & 3 \\
5 & Provides freedom followed by responsibility & 3 \\
& Total & 15 Questions \\
\hline
\end{tabular}

Table 2. Learning Discipline Questionnaire Blueprint

\begin{tabular}{|c|c|c|c|}
\hline No & Dimension & Indicators & $\begin{array}{c}\text { Total } \\
\text { Questions }\end{array}$ \\
\hline \multirow[t]{2}{*}{1} & The discipline of activeness and & a. School attendance rate & 4 \\
\hline & suitability of attendance at school & $\begin{array}{l}\text { b. The suitability of the time students } \\
\text { enters the school and class } \\
\text { environment }\end{array}$ & 4 \\
\hline \multirow[t]{2}{*}{2} & $\begin{array}{l}\text { Discipline when carrying out } \\
\text { learning activities at }\end{array}$ & $\begin{array}{l}\text { a. Participation of students in } \\
\text { teaching and learning activities }\end{array}$ & 4 \\
\hline & Class & $\begin{array}{l}\text { b. Complete practice questions are } \\
\text { given by the teacher }\end{array}$ & 4 \\
\hline \multirow[t]{3}{*}{3} & $\begin{array}{l}\text { Discipline in completing } \\
\text { assignments and following tests }\end{array}$ & $\begin{array}{l}\text { Do tasks actively and independently } \\
\text { b. Follow test instructions and rules }\end{array}$ & 4 \\
\hline & & $\begin{array}{l}\text { c. Collect assignments according to } \\
\text { the time of collection }\end{array}$ & 4 \\
\hline & & & 4 \\
\hline \multirow[t]{4}{*}{4} & $\begin{array}{l}\text { Discipline in organizing study } \\
\text { activities at home }\end{array}$ & $\begin{array}{l}\text { a. Able to condition oneself to study } \\
\text { at home actively and } \\
\text { independently }\end{array}$ & 4 \\
\hline & & $\begin{array}{l}\text { b. Complete the given homework } \\
\text { with great enthusiasm and }\end{array}$ & 4 \\
\hline & & effectiveness & 4 \\
\hline & & $\begin{array}{l}\text { c. Set up a special time for studying at } \\
\text { home }\end{array}$ & \\
\hline \multirow[t]{3}{*}{5} & $\begin{array}{l}\text { Discipline in obeying the rules } \\
\text { that apply in school }\end{array}$ & $\begin{array}{l}\text { a. Wearing school uniforms and } \\
\text { attributes }\end{array}$ & 4 \\
\hline & & $\begin{array}{l}\text { b. Participate in flag ceremony } \\
\text { activities }\end{array}$ & 4 \\
\hline & & $\begin{array}{l}\text { c. Prepare the necessary learning } \\
\text { equipment }\end{array}$ & 4 \\
\hline
\end{tabular}




\begin{tabular}{lll}
\hline & $\begin{array}{l}\text { d. Active in maintaining order and } \\
\text { cleanliness of the school } \\
\text { environment }\end{array}$ & 4 \\
& $\begin{array}{l}\text { e. Carry out picket duties with a full } \\
\text { sense of responsibility }\end{array}$ & \\
\hline Total & & 60 Questions \\
\hline
\end{tabular}

The questionnaire used a Likert scale pattern. After the questionnaire was compiled, the validity test was then carried out to determine the appropriate statement for use and the reliability test to determine the consistency level of the questionnaire instrument. The test was carried out at one randomly appointed school. Based on the test results, it was known that from the 15 statements in the questionnaire for the type of democratic parenting, 11 statements were valid, and the level of reliability was high with a value of $\mathrm{r} 11=0.7$. Whereas in the learning discipline questionnaire, there were 28 valid statement items, and the level of reliability was high with a value of $r 11=0.89$. Valid statements from the two questionnaires were then used to assess the questionnaire score of each population in this study.

The research method used was a statistical analysis method consisting of descriptive statistical analysis and inferential statistical analysis. Descriptive statistical analysis was used to obtain broad conclusions through the process of data analysis, which was described in the data frequency distribution, mean and mode values and can be in the form of graphic diagrams. The testing of the research hypothesis was carried out using inferential statistical analysis. The final results obtained in this analysis are the conclusions of a study. This test was carried out on data that would be processed using inferential statistical test formulas. Before the data is used in hypothesis testing, the prerequisites are tested first. After the prerequisite test was carried out, the data was used to test the research hypothesis. Tests are carried out using multiple regression analysis techniques. The regression analysis test was a test used to predict or predict the changes that occur in the dependent variable when the values of the independent variable are changed, or manipulated (Sugiyono, 2017).

\section{Result and Discussion}

The prerequisite test was carried out before the data was used to test the research hypothesis. Some of the prerequisite tests used were the residual normality test, linearity test, multicollinearity test, and heterox-plasticity test. The data presented in this study were data on the competence of mathematics knowledge of class V (Y) students as well as questionnaire data on the type of democratic parenting and learning discipline. Mathematical knowledge competency data were obtained through the document recording method. The data used were the odd semester math knowledge competency report cards (KI3). Meanwhile, data on the type of democratic parenting and learning discipline were obtained by distributing questionnaires that have been carried out by researchers in schools. The description of the competency data for mathematical knowledge that has been obtained is as follows.

Table 3. Description of Mathematical Knowledge Competency Data

\begin{tabular}{lc}
\hline Statistics Analytic & Mathematical Knowledge Competencies \\
\hline Sample & 118 \\
Maximum Score & 92 \\
Minimum Score & 65 \\
Mean & 77.06 \\
Standard Deviation & 6.87 \\
Variants & 67.22 \\
\hline
\end{tabular}

Based on the following table of data distribution, it is known that the average competency score of students' mathematical knowledge is 77.06. This value is in the interval $65-79$, so it is in the good enough category. Therefore, it is obtained information that the competence of students' mathematical knowledge is quite good. 
Table 4. Description of Data on Types of Democratic Parenting

\begin{tabular}{lc}
\hline Statistics Analytic & Democratic Parenting Types \\
\hline Sample & 118 \\
Maximum Score & 43 \\
Minimum Score & 33 \\
Mean & 36.68 \\
Standard Deviation & 2.76 \\
Variants & 7.64 \\
\hline
\end{tabular}

Based on the following table of data distribution, it can be seen that the average value of the democratic parenting style questionnaire is 36.68 . The average value lies in the interval $35.75-4$, so it is included in the very dominant category. Therefore, it is obtained information that the type of democratic parenting is very dominant in grade $\mathrm{V}$ students

Table 5. Description of Learning Discipline Data

\begin{tabular}{lc}
\hline Statistics Analysis & Learning Discipline \\
\hline Sample & 118 \\
Maximum Score & 113 \\
Minimum Score & 69 \\
Mean & 94.21 \\
Standard Deviation & 8.83 \\
Variants & 78.05 \\
\hline
\end{tabular}

Based on the following data distribution table, it can be seen that the average value of the learning discipline questionnaire is 94.21. The average value lies in the interval $79.75-94.25$ which is in the good category. Therefore, information is obtained that grade $\mathrm{V}$ students have a relatively good quality of learning discipline.

The data that will be used to test the hypothesis must meet the assumptions in the study. One of the assumptions that must be fulfilled is that the data residuals must be normally distributed. Therefore, a normality test was carried out on the residual data of the variables used in this study. This test is carried out using the Kolmogorov-Smirnov test, namely by testing the residual data of each variable, namely the residual data for the X1Y variable, the X2Y variable data, and the X1X2Y variable data residual. The residual normality test was carried out with the help of the Microsoft Office Excel 2013 application. The results of the residual normality test are presented in the following table.

Table 6. Data Residual Normality Test

\begin{tabular}{|c|c|c|c|}
\hline Variable & |Ft-Fs| Max & KS Table & Conclusion \\
\hline $\begin{array}{l}\text { Types of Democratic Parenting and } \\
\text { Mathematical } \\
\text { Competencies (X1Y) }\end{array}$ & 0.108 & 0.125 & $\begin{array}{l}\text { Residual Data in } \\
\text { Normal } \\
\text { Distribution }\end{array}$ \\
\hline $\begin{array}{l}\text { Learning Discipline and } \\
\text { Mathematical } \\
\text { Competencies (X2Y) }\end{array}$ & 0.091 & 0.125 & $\begin{array}{l}\text { Residual Data in } \\
\text { Normal } \\
\text { Distribution }\end{array}$ \\
\hline $\begin{array}{l}\text { Types of Democratic } \text { Parenting, } \\
\text { Learning } \text { Discipline r and } \\
\text { Mathematical } \\
\text { Competencies (X1X2Y) }\end{array}$ & 0.065 & 0.125 & $\begin{array}{l}\text { Residual Data in } \\
\text { Normal } \\
\text { Distribution }\end{array}$ \\
\hline
\end{tabular}

Data that has been tested for normality then tested for data linearity. This test is carried out to determine the relationship between the independent variables and the dependent variable. The criteria in the linearity test with the Definition of Linearity is if the significance value is more than 0.05 , then the relationship between variable $\mathrm{X}$ and variable $\mathrm{Y}$ is linear. Tests carried out on variable 
data X1 and Y obtained a significance value of $0.395>0.05$. So it can be concluded that the relationship that occurs between variables $\mathrm{X} 1$ and $\mathrm{Y}$ is linear. The linearity test carried out on the variable data $\mathrm{X} 2$ and $\mathrm{Y}$ also shows that there is a linear relationship, this is known from the significance value $=$ $0.898>0.05$. The two independent variables used in this study must be tested whether they have a strong correlation or not. So, to prove this, the Multicollinearity test was carried out (Dantes, 2017). The test was carried out using the IBM SPSS 21 application. The results obtained from this test were a Tolerance value of 0.566 and a VIF value of 1.768 . This shows that the regression model does not find any multicollinearity symptoms, because the VIF value obtained is less than 10 , and the tolerance value obtained is more than 0.1 . A heteroscedasticity test is performed to determine whether there is an inequality of variance from one observation value to another in a regression model. This test uses the Glejser test technique which refers to the comparison of the significance value obtained and the absolute value of the variable residual (abs_res). The significance value and absolute value of the residual variables were obtained from testing using the IBM SPSS 21 application. Based on the test results, the first variable's significance value was 0.313 , and the second variable's significance value was 0.146 . Both values are more than 0.05 , so it can be concluded that in this regression model, there are no symptoms of heteroscedasticity.

The hypothesis tested at this stage is H0, that is, there is no effect of the application of the type of democratic parenting and learning discipline on the competence of mathematical knowledge of class $\mathrm{V}$ students. Hypothesis testing is carried out after the data has passed the assumptions test as a condition for testing the hypothesis. The analysis used in testing the hypothesis of this study is using multiple regression analysis using the equation $\hat{Y}=a+b 1 X 1+b 2 X 2$ (Rangkuti. The values of the equations that have been obtained are then included in the regression equation, so the equation obtained is $\hat{Y}=8.205+0.958$. X $1+0.358 X 2$. This shows that each increase of 1 score, both from variable $\mathrm{X} 1$ and variable $\mathrm{X} 2$, affects the increase in the score of variable $\mathrm{Y}$ by 0.985 and 0.358 , at a constant of 8,205 . The value of the regression equation that has been obtained can be described through a regression following diagram.

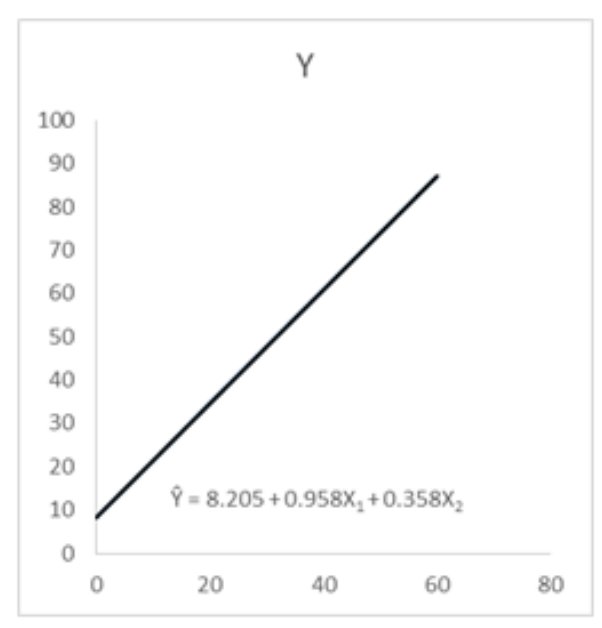

Gambar 2. Garis Regresi $\hat{Y}=8.205+0.958 X 1+0.358 X 2$

Furthermore, testing the null hypothesis using the $\mathrm{F}$ test. The results of the tests that have been carried out, obtained the value of F-reg $=84.209$ and F-table $=3.075$. Therefore it can be concluded that there is a significant influence between the type of democratic parenting and learning discipline on the mathematics knowledge competence of the fifth-grade students of SDN Gugus I Gusti Ngurah Jelantik, Denpasar Utara District with a coefficient of determination (R2) $=0.549$ so that it is found that the competence of mathematical knowledge Class V students are influenced by the application of the type of democratic parenting and learning discipline with the percentage of influence of $59.4 \%$ and there are still other factors that can affect the competence of students' mathematical knowledge. The following is a summary table of the results of multiple regression analysis. 
Table 7. Multiple Regression Analysis

\begin{tabular}{lccclll}
\hline Source & JK & Db & RK & \multicolumn{2}{c}{ Fempiric } & Ftheoritic Interpretation \\
\hline Regression & 3282.923 & 2 & 1641.462 & 84.209 & 3.075 & significant \\
Residual & 2241.661 & 115 & 19.493 & & & \\
\hline
\end{tabular}

Based on the results of the data analysis that has been done, it is known that the competence of mathematical knowledge can be influenced by the application of democratic parenting styles and the quality of student discipline in learning. The education that children get from their parents is very influential in psychological development and character-building (Utami \& Utaminingsih, 2017). In addition, the application of proper parenting will also affect student learning habits (Sibawaih, 2017). All of that can work well if good communication between parents and children goes well. This is because communication will enable children to convey all the problems they face, especially problems in learning (Eliyawati \& Meiyuntariningsih, 2018). So that both parents and children can work together, find the best solution to solve children's learning problems, so that parents also play a role in supporting children in learning activities at home, such as creating an ideal atmosphere for children to study at home and other endeavors.

Fitasari, (2019) obtain results from research related to the theory used in this study. The results obtained are that there is a significant influence on the application of democratic parenting to learning outcomes of mathematics. The amount of influence exerted by the independent variable is $26.8 \%$. This shows that the application of democratic parenting can have a positive influence on student learning outcomes. So that the type of democratic parenting is well applied by parents in educating and caring for their children at home. Another research conducted by Widhiasih, (2017) also shows that the application of parenting affects student learning outcomes. The results obtained in this study were students who applied democratic parenting obtained high social studies learning outcomes with an influence percentage of 39.5\%. Similar results were obtained by Santi, (2019). The research he conducted obtained results, namely that there was a significant correlation between the application of parenting styles to the competence of social science knowledge with 38.5\%

To be able to master the competence of mathematical knowledge, students must be able to learn in optimal situations. One of the things that can affect these learning conditions is student discipline in learning (Sari \& Hadijah, 2017). So that learning discipline is the key for students in learning (Sugiarto \& Yulianti, 2019). When students participate in in-class learning, students should be able to control themselves and obey all the rules that exist when learning activities take place. When the teacher explains the material, students are expected to be able to concentrate fully, to understand the explanation given by the teacher. In addition, discipline in learning will further hone skills in remembering the material provided by the teacher, this is because students learn with full awareness, so that ultimately students will be more motivated to learn (Aslianda et al., 2017). However, learning discipline is not only assessed when students participate in in-class learning but are also assessed by the way students complete the assignments were given by the teacher. Students who have good discipline, of course, can endeavor themselves to do the assigned assignments well and collect them according to the set time.

Research conducted by Diatmika et al., (2017) shows that there is a significant positive correlation between the discipline in learning and the social science competence knowledge of grade IV students. These results support the theory used in this study. In addition, research conducted by Yulia, (2017) also obtained results that reinforce the results of this study. The results obtained are that there is a positive and significant relationship between learning discipline and learning concentration on mathematics learning outcomes of grade IX SMP students. The results of other studies that also support the results obtained research from Dewi (2019) the result is that there is a significant relationship between learning discipline and mathematics learning outcomes with a contribution of $22.5 \%$. The three research results that have been described indicate that learning discipline can affect student learning outcomes, both at the elementary level and at higher levels.

Based on this explanation, it is known that the theory used is in line with the results of other studies that are relevant to this study. This strengthens the analysis results that have been obtained in hypothesis testing. So, from the data analysis and the previous explanation, it can be concluded that the application of democratic parenting styles and learning disciplines has a simultaneous effect on the competence of students' mathematical knowledge. 


\section{Conclusion}

Based on the results of data analysis and testing of research hypotheses, the results obtained were that there was a significant effect of the application of the type of democratic parenting and learning discipline on the competence of mathematics knowledge of class V students. Proper parenting can have a positive influence on children's learning activities, both at home and at school. This will also have an impact on student learning outcomes at school. And parents and teachers are expected to be able to work together with students to get used to being able to be disciplined while studying. With learning discipline, the learning atmosphere becomes more conducive, fun to learn, and learning activities become more meaningful and right on target.

\section{References}

Adinoto, P. (2019). Pengaruh Kegiatan Awal Pembelajaran, Disiplin Belajar Dan Motivasi Belajar Terhadap Prestasi Belajar. Jurnal Imiah Pendidikan Dan Pembelajaran, 3(1), 53. http://dx.doi.org/10.23887/jipp.v3i1.17110

Agustika, G. N. S., Kartika, A. A. W., \& Wiarta, I. W. (2019). Efektivitas Model Pembelajaran Kooperatif Tipe Pair Checks Ditinjau dari Kecerdasan Interpersonal terhadap Kompetensi Pengetahuan Matematika. Jurnal Ilmiah Sekolah Dasar, 3(3), 293-302. http://dx.doi.org/10.23887/jisd.v3i3.19454

Aslianda, Z., Israwati, \& Nurhaidah. (2017). Hubungan Disiplin Belajar Terhadap Hasil Belajar SIswa Kelas IV Sekolah Dasar Negeri 18 Banda Aceh. Jurnal Ilmiah Pendidikan Guru Sekolah Dasar, 2(1), 236-243. http://www.mendeley.com/research/hubungan-disiplin-belajar-terhadaphasil-belajar-siswa-kelas-iv-sekolah-dasar-negeri-18-banda-aceh-z/. http://www.jim.unsyiah.ac.id/pgsd/article/view/2552

Dantes, Nyoman. 2017. Desain Eksperimen dan Analisis Data. Depok : Rajawali Pers

Dermawan, M. D., Abdullah, R., Rifwan, F., \& Gusmareta, Y. (2018). Hubungan Perhatian Orang Tua Dengan Hasil Belajar Gambar Konstruksi Bangunan SIswa Kelas XI TGB SMK Negeri 1 Tanjung Raya. CIVED JURUSAN TEKNIK SIPIL, 5(1), 2124-2128. https://doi.org/10.24036/cived.v5i1.9932

Dewi, K. M. S. (2019). Kontribusi Disiplin Belajar dan Motivasi Berprestasi Terhadap Hasil Belajar Matematika. Journal of Lesson and Learning Studies, 1(2), 149-162. http://dx.doi.org/10.23887/jlls.v2i1.17328

Diatmika, I. G. N., Sujana, I. W., \& Putra, M. (2017). Korelasi Antara Disiplin Dalam Belajar Dengan Kompetensi Pengetahuan Ips Siswa Kelas Iv Sd Gugus 1 Kecamatan Mengwi Tahun Pelajaran 2016/2017. Journal of Education Technology, 1(3), 156. http://dx.doi.org/10.23887/jet.v1i3.12499

Eliyawati, R., \& Meiyuntariningsih, T. (2018). Peran orang tua terhadap prestasi belajar anak. Jurnal Abdikarya: Jurnal Karya Pengabdian Dosen Dan Mahasiswa, 01(02), 2-4. https://doi.org/10.30996/abdikarya.v1i2.2071

Fitasari, N. P. D. (2019). Pengaruh Pola Asuh Orang Tua Terhdap Hasil Belajar Matematika dengan Efikasi Diri Sebagai Intervening. International Journal of Elementary Education., 3(4), 404-412. http://dx.doi.org/10.23887/ijee.v3i4.21313

Haqqi, A. (2019). Kedisiplinan Belajar Siswa di Sekolah Dasar ( SD ) Negeri Cot Keu Eung Kabupaten Aceh Besar ( Studi Kasus ). Jurnal of Education Science, 5(2), 1-12. https://doi.org/10.3314/jes.v5i2.467

Ismiyanti, Y. (2018). Pengaruh Minat Dan Kedisiplinan Terhadap nilai UAS IPS di SDN 02 Temulus. Jurnal Ilmiah Pendidikan Dasar, V(1), 34-43. http://dx.doi.org/10.30659/pendas.5.1.34-43

Juniarti, N. K. R., Margunayasa, I. G., \& Kusumariyatni, N. (2020). Hubungan Antara Pola Asuh Orang 
Tua dan Konsep Diri dengan Kompetensi Pengetahuan Matematika Siswa. Jurnal Ilmiah Sekolah Dasar, 4(1), 17-25. http://dx.doi.org/10.23887/jisd.v4i1.24273

Khoirurrohman, T. (2018). Pengaruh Pola Asuh Orang Tua Terhadap Kemandirian Siswa Kelas IV SD Sekecamatan Butuh Kabupaten Purwerejo. JURNAL DIALEKTIKA JURUSAN PGSD, 8(1), 8-17. https://journal.peradaban.ac.id/index.php/jdpgsd/article/view/229

Lestari, A., \& Sugeng. (2019). Pengaruh Disiplin Belajar, Lingkungan Sosial, dan Variasi Gaya Mengajar Guru Terhadap Hasil Belajar Matematika Siswa Kelas XI IPA SMAN 5 Samarinda. Jurnal PRIMATIKA, 8(1), 1-10. https://doi.org/10.30872/primatika.v8i1.134

Nugraheni, S. (2019). Hubungan Antara Motivasi Belajar Dengan Disiplin Belajar Siswa. Journal for Lesson and Learning Studies, 2(1), 30-36. http://dx.doi.org/10.23887/jlls.v2i1.17317

Oktarini, K., Suarjana, I., \& Arini, N. W. (2018). Hubungan Pola Asuh Orang Tua dan Percaya Diri dengan Hasil Belajar Matematika. Jurnal Pendidikan Dan Pengembangan, 1(2), 76-83. http://dx.doi.org/10.23887/ip2.v1i2.19326

Prabaningrum, I. G. A. I. (2019). Pengaruh Model Pembelajaran Kooperatif Team Assisted Individualization Berbantuan Media Semi Konkret Terhadap Kompetensi Pengetahuan Matematika. Jurnal Ilmiah Sekolah Dasar, 3(4), 405-413. http://dx.doi.org/10.23887/jisd.v3i4.21775

Reswita. (2017). Hubungan Pola Asuh Orangtua dengan Capaian Perkembangan Anak. PAUD Lectura: Jurnal Pendidikan Anak Usia Dini, 1(1), 72-81. https://doi.org/10.31849/paudlectura.v1i1.506

Santi, E. M. W. (2019). Hubungan Pola Asuh Orang Tua dan Kecerdasan Intrapersonal dengan Penguasaan Kompetensi Pengetahuan IPS Siswa Kelas IV. JP2SD Uurnal Pemikiran Dan Pengembangan Sekolah Dasar), 7(2), 98-109. https://doi.org/10.22219/ip2sd.v7i2.8937

Santosa, A. I., Rafli, Z., \& Lustyantie, N. (2018). Pengaruh Pola Asuh Orang Tua dan Sikap Bahasa terhadap Kemampuan Membaca Pemahaman The Influence of Parenting Style and Language Attitude toward the Reading Comprehension Achievement. Jurnal Pendidikan Bahasa Dan Sastra, 18(April), 69-80. https://doi.org/10.17509/bs _jpbsp.v18i1.12147

Sari, B. P., \& Hadijah, H. S. (2017). Meningkatkan Disiplin Belajar Siswa melalui Manajemen Kelas. $\begin{array}{lllll}\text { Jurnal Pendidikan } & \text { Manajemen } & \end{array}$ https://doi.org/10.17509/ipm.v2i2.8113

Sibawaih, I. (2017). Analisis pola asuh orang tua terhadap gaya belajar siswa di sekolah menengah atas kharismawita jakarta selatan. 3(2), 172-185. http://dx.doi.org/10.30998/rdje.v3i2.2014

Sugiarto, A. P., \& Yulianti, P. D. (2019). Faktor kedisiplinan belajar pada siswa kelas x smk larenda brebes. Jurnal Mimbar Ilmu, 24(2), 232-238. http://dx.doi.org/10.23887/mi.v24i2.21279

Sugiyono. 2017. Metode Penelitian Kuantitatif, Kualitatif dan R\&D. Bandung : Alfabeta

Ulhusna, M., \& Diana, S. (2020). Permainan Ludo untuk Meningkatkan Keterampilan Kolaborasi Siswa dalam Pembelajaran Matematika. International Journal of Elementary Education., 4(1), 130-138. http://dx.doi.org/10.23887/ijee.v4i2.23050

Utami, N. K., \& Utaminingsih, D. (2017). Hubungan Antara Pola Asuh Orang Tua Dengan Motivasi Belajar. ALIBIKIN Uurnal Bimbingan Konseling), 1. http://jurnal.fkip.unila.ac.id/index.php/ALIB/article/view/14373

Widhiasih, I. (2017). Pengaruh pola asuh orang tua terhadap hasil belajar ips. Jurnal Kreatif: Jurnal Kependidikan Dasar. https://doi.org/10.15294/kreatif.v7i2.9380

Widiasih, N. L. N. S., Wiarta, I. W., \& Ardana, I. K. (2018). Pengaruh Model Pembelajaran Team Assisted Individualization Berbasis Penilaian Kinerja Terhadap Kompetensi Pengetahuan Matematika 
SIswa Kelas V SD Gugus II Kuta Utara Tahun Pelajaran 2017/2018. Journal for Lesson and Learning Studies, 1(2), 102-109. http://dx.doi.org/10.23887/jlls.v1i2.14717

Yulia, P. (2017). Hubungan Disiplin Belajar Dan Konsentrasi Belajar Terhadap Hasil Belajar Matematika Siswa. PYTHAGORAS: Jurnal Program Studi Pendidikan Matematika, 6(2), 100-105. http://dx.doi.org/10.33373/pythagoras.v6i2.905

Zuliantini, Y., \& Mayasari, S. (2018). Hubungan Antara Pola Asuh Orang Tua Dengan Prestasi Belajar. 1. http://jurnal.fkip.unila.ac.id/index.php/ALIB/article/view/14869 